\title{
Keintiman Komunikasi Keluarga saat Social Distancing Pandemi Covid-19
}

\author{
Andalusia Neneng Permatasarii ${ }^{1}$, Dinar Nur Inten ${ }^{2}$, Wiliani ${ }^{3}$, Kelik Nursetiyo Widiyanto ${ }^{4}$ \\ Ilmu Komunikasi, Universitas Islam Bandung $1,3,4$ \\ Pendidikan Guru Pendidikan Anak Usia Dini, Universitas Islam Bandung2 \\ DOI: $10.31004 /$ obsesi.v5i1.577
}

\begin{abstract}
Abstrak
Penelitian ini bertujuan untuk menjelaskan keintiman komunikasi keluarga yang dibangun pada masa social and physical distancing akibat pandemi Covid-19. Penelitian ini juga memperlihatkan perbedaan keintiman ketika sebelum social and physical distancing dan ketika masa social and physical distancing akibat pandemi Covid-19. Metode yang digunakan dalam penelitian ini adalah metode kualitatif dengan pendekatan studi kasus. Hasil dari penelitian ini adalah kuantitas waktu yang dimiliki untuk keluarga karena kebijakan social and physical distancing menjadi lebih banyak jika dibandingkan sebelum social and physical distancing. Waktu belajar dan bermain dengan anak lebih banyak. Namun, sering juga terjadi bentrok antara orang tua dengan anak. Keintiman dibangun oleh durasi waktu yang panjang. Dari hasil penelitian diperoleh informasi bahwa keintiman keluarga dibangun dari kemampuan memahami peran masing-masing, memahami diri sendiri, dan menyampaikan serta menerjemahkan pesan dengan baik. Baik itu ayah atau suami, ibu atau istri, dan anak. Keintiman tidak berpatokan pada waktu yang banyak.
\end{abstract}

Kata Kunci: komunikasi keluarga, social distancing, covid-19

\begin{abstract}
This study aims to explain the intimacy of the family of communication that was built during the social and physical distancing caused by the Covid-19 pandemic. This study also shows differences in intimacy when before social and physical distancing and when social and physical periods were disturbances due to the Covid-19 Pandemic. The method used in this research is a qualitative method with a case study approach. The results of this study are all of informants admitted that they have more time with family because of social and physical distancing policies more than before social and physical distancing. We have more time to playing and learning with children but however clashes often occur too. However, that does not mean intimacy is built by a long duration of time. From the research results obtained information that family intimacy is built from the ability to understand each other's roles, understand themselves, and convey and translate messages properly. Intimacy does not depend on time.
\end{abstract}

Keywords: Family Communication; social distancing; and Covid-19.

Copyright (c) 2020 Andalusia Neneng Permatasari, Dinar Nur Inten, Wiliani, Kelik Nursetiyo Widiyanto

$\triangle$ Corresponding author :

Email Address : andalusianp@gmail.com/andalusia@unisba.ac.id (Jl. Tamansari No 1, Bandung)

Received 2 June 2020, Accepted 9 June 2020, Published 21 June 2020 


\section{PENDAHULUAN}

Seiring meluasnya pasien yang terjangkit Covid-19 di Tanah Air, Presiden Joko Widodo mengimbau masyarakat untuk sementara belajar, bekerja, dan beribadah di rumah. Hal tersebut dilakukan sebagai upaya pengendalian penularan penyakit dengan menerapkan pembatasan interaksi sosial langsung (BBC Indonesia, 2020). Di Wuhan, virus ini pun menyebar sangat cepat (Su et al., 2020). Imbauan Presiden itu pun langsung dilanjutkan dengan edaran resmi dari Menteri Kesehatan.

Menteri Kesehatan, Terawan Agus Putranto, mengeluarkan Surat Edaran Nomor HK.02.01/MENKES/202/2020 tentang Protokol Isolasi Diri Sendiri dalam Penanganan Coronavirus Disease. Surat edaran yang ditujukan kepada pemimpin kementerian atau lembaga, gubernur, dan bupati/ wali kota tersebut ditandatangani pada 16 Maret 2020 (Nafi, 2020). Menindaklanjuti surat edaran tersebut, Pemerintah Provinsi Jawa Barat resmi mengumumkan untuk meniadakan aktivitas belajar mengajar siswa PAUD, TK, SD, SMP, dan SMA di wilayah Jabar. Pemberlakuan kebijakan belajar di rumah tersebut akan berlangsung selama dua pekan ke depan, mulai dari 16-30 Maret 2020 (CNN Indonesia, 2020).

Tidak hanya anak sekolah, imbauan presiden tersebut direspons juga oleh berbagai institusi yang akhirnya memberlakukan bekerja di rumah bagi para karyawan. Tidak terkecuali kampus atau perguruan tinggi. Institusi pendidikan ditantang untuk menyelenggarakan kegiatan belajar mengajar secara virtual (Baloran, 2020). Keadaan ini memunculkan sebuah pemandangan baru yang muncul kala imbauan presiden sudah berlaku, yaitu berkumpulnya anggota keluarga di rumah. Misalnya saja, dengan kebijakan tersebut, anak-anak mulai menjalankan belajar di rumah yang tentu saja membutuhkan orang tua untuk turun tangan. Jika selama ini orang tua menitipkan pendidikan anak pada institusi sekolah, sekarang ini orang tua (apa pun kesibukannya) mau tidak mau harus turun tangan membantu proses belajar anak-anak di rumah.

Tidak hanya soal belajar di rumah, kebosanan akan dirasakan anggota keluarga, apalagi jika seluruh anggota keluarga tipikal orang yang senantiasa selalu mobile berkegiatan atau beraktivitas. Anak yang biasanya bermain bersama kawan. Ayah yang biasanya beraktivitas dan berinteraksi di kantor. Ibu yang bekerja tentu punya kegiatan juga di luar. Aktivitas rutin itu seketika hilang yang bisa jadi memunculkan rasa bosan atau kecemasan (Baloran, 2020). Oleh karena itu, di tengah kebijakan karantina diri ini, ada beberapa keluarga memunculkan kegiatan-kegiatan baru yang bisa dilakukan bersama tanpa harus keluar rumah.

Intensitas interaksi, durasi waktu yang lebih lama, dan aneka kegiatan yang dilakukan bersama-sama, adalah hal-hal yang bagi sebagian keluarga itu sudah jarang bisa dilakukan ketika imbauan stay at home diberlakukan. Tidak cukupnya waktu di rumah, interaksi yang jarang, dan tidak adanya kegiatan yang dapat dilakukan bersama, dapat menyebabkan hilangnya keintiman dalam keluarga karena kurangnya komunikasi. Kurangnya komunikasi akan menghambat perkembangan kepribadian dan menyebabkan keterpecahbelahan (Rakhmat, 1999).

Keintiman dalam komunikasi antarpersona diekstraksikan menjadi tiga hal, yaitu established relationship, dyadic primacy, dan dyadic coalition (DeVito, 2008). Komunikasi antarpersona berangkat dari dua orang dengan hubungan yang baik, erat, dan mapan (atau bisa dikatakan kuat), hubungan personal yang saling menguntungkan, dan kesadaran tinggi dalam berinteraksi antara dua belah pihak.

Keintiman dalam komunikasi antarpersona harus juga muncul dalam konteks di lingkungan keluarga. Keintiman adalah syarat mutlak dalam komunikasi antarpersona (DeVito, 2008). Keintiman menurut Levinger (Masters, W. H., Johnson, V. E., 1992) adalah proses dari dua orang yang saling memberikan perhatian sebebas mungkin dalam pertukaran perasaan, pikiran dan tindakan. Secara umum, keintiman dalam hal ini meliputi perasaan penerimaan, kedekatan, komitmen, dan kedekatan dari kedua belah pihak. 
Keintiman ini harus dirasakan dan terjadi pada hubungan suami dan istri, ayah dan anak, ibu dan anak, serta anak dan anak lagi (siblings).

Tiap anggota keluarga harus dapat mengekspresikan perasaan dan menyampaikan gagasan secara bebas dan nyaman. Suami dan istri harus dapat saling menerima, begitu pula orang tua ke anak dan sebaliknya. Kedekatan pun harus terbangun untuk membentuk keintiman yang akan menjadi kunci suksesnya komunikasi antarpersona di lingkungan keluarga.

Keintiman di keluarga itu bukan sesuatu yang dapat diperoleh dengan mudah dan menunggu begitu saja. Itu adalah sesuatu yang harus diusahakan dan diciptakan dengan itikad dari masing-masing anggota keluarga. Dilihat dari sisi keintiman dalam hubungan interpersonal, maka hubungan sosial yang terjalin harus memenuhi apa yang dinamakan "need for intimacy". Batasan pengertian tentang intimacy, antara lain sebagai berikut. a) Intimacy melibatkan rasa saling memiliki (sense of belonging), yaitu kebutuhan untuk membuat hubungan kuat, stabil, dan dekat, b) Intimacy merupakan elemen emosional dalam suatu hubungan yang melibatkan pengungkapan diri (self disclosure), yang akan menghasilkan suatu keterikatan, kehangatan, dan kepercayaan, dan c) Intimacy adalah hubungan yang cukup kuat yang berlangsung dengan orang lain, yaitu ketika individu dapat saling berkorban untuk kesejahteraan satu sama lain tanpa harus kehilangan identitas masing-masing individu (Johnson, 2016).

Dari pengertian keintiman tersebut, dapat kita tarik konsep kunci keintiman adalah kedekatan, keterbukaan, kestabilan, dan kesejahteraan. Adanya kebijakan untuk belajar di rumah, bekerja di rumah, dan social distancing akibat serangan pandemi covid 19 ini, ada hal yang dapat didiskusikan dengan melihat interaksi keluarga akibat adanya kebijakan tersebut. Orang tua akhirnya harus mendampingi anak belajar jarak jauh di rumah. Orang tua juga harus membuat anak betah di rumah agar tidak bermain di luar. Suami yang biasanya menghabiskan banyak waktu bekerja di kantor, kini dapat mempunyai waktu lebih luang bersama istri untuk mengerjakan pekerjaan rumah. Ibu bekerja yang biasanya sangat sulit mencari waktu untuk anak-anak, kini seharian bisa bersama anak-anak beraktivitas apa pun. Oleh karena itu, penelitian ini bertujuan memaparkan keintiman keluarga yang dibangun pada masa social and physical distancing akibat pandemi Covid-19.

Penelitian berjudul "Phillipine Teacher's Practices to Deal with Anxiety amid Covid-19" menunjukkan fenomena kekhawatiran atau anxiety yang terjadi di kalangan guru di Filipina. Penelitian ini memperoleh data para guru dalam pencarian informasi mengenai Covid-19, langkah pencegahan yang mereka tempuh, dan sikap yang mereka lakukan dalam mencegah serangan khawatir dalam proses karantina diri. Hasil dari penelitian ini adalah cara para guru agar terhindar dari kekhawatiran berlebihan adalah dengan berlatih mengajar daring, menjalin komunikasi secara daring dengan komunitas profesional, dan memiliki aktivitas yang bermanfaat agar bisa berdamai dengan keadaan yang serba tidak jelas selama karantina (Talidong \& Toquero, 2020).

Penelitian yang terkait interaksi di keluarga dibahas pada jurnal yang berjudul "Child-Mother and Child-Father Play Interaction Patterns with Preschoolers". Penelitian ini memperoleh hasil bahwa ibu jika berinteraksi dengan anak cenderung pada hal terstruktur, petunjuk, mengajari, dan membuat ikatan dengan obrolan empatik. Lain halnya dengan ayah yang cenderung berinteraksi dengan permainan fisik, bersikap seperti teman sebaya, mengikuti instruksi anak, dan menantang keberanian anak (John, Halliburton, \& Humphrey, 2013).

Penelitian terkait komunikasi keluarga juga dilakukan pada penelitian yang berjudul "Pengaruh Komunikasi Orang Tua dalam Rumah Tangga terhadap Akhlak Sehari-hari". Hasil dari penelitian ini menunjukkan bahwa pengaruh komunikasi orang tua terhadap anak dalam rumah tangga terhadap akhlak anak sehari-hari ternyata berkualifikasi tinggi. Komunikasi efektif yang dibangun sangat signifikan mempengaruhi akhlak anak (Muftie, 2017). 
Frekuensi komunikasi di keluarga juga dapat mempengaruhi prestasi anak. Penelitian yang berjudul "Pengaruh Komunikasi Keluarga terhadap Prestasi Belajar Anak" menghasilkan bahwa (1) kredibilitas ayah dalam mengawasi belajar dan berinteraksi dengan anak tidak memengaruhi prestasi belajar karena terbatasnya kuantitas waktu yang dimiliki; (2) kredibilitas ibu dalam mengawasi belajar anak dan berinteraksi dapat mendukung prestasi belajar anak di sekolah; (3) frekuensi komunikasi yang dilakukan ayah secara langsung kepada anak menentukan prestasi belajar yang diraih anak; dan (4) frekuensi komunikasi yang tinggi tidak menentukan prestasi belajar anak menjadi tinggi (Kurniadi, 2001).

Selanjutnya, ada penelitian mengenai komunikasi dan pengasuhan anak di dalam keluarga. Penelitian yang berjudul "Komunikasi Pola Asuh Anak Balita-Remaja dalam Keluarga Betawi Jakarta dan Bekasi" menghasilkan sebuah temuan pola komunikasi pengasuhan anak di Kampung Tugu Jakarta Utara dipengaruhi dari cara-cara generasi sebelumnya. Masyarakat Betawi di Kampung Condet Jakarta Timur lebih mengembangkan tradisi keluarga yang dipengaruhi cara-cara budaya Arab. Masyarakat Betawi di Kampung Ujung Harapan Bekasi mayoritas beragama Islam sehingga pola pengasuhan anak pun didominasi dengan cara Islam yang diwariskan dari generasi sebelumnya. Pola pengasuhan di Kampung Tugu lebih dominan mendidik remaja. Adapun masyarakat Kampung Condet dan Kampung Ujung Harapan fokus dan konsisten mendidik balita dan remaja (Sari, 2014).

Beberapa penelitian terdahulu yang disebutkan sebelumnya itu membahas komunikasi anak dan orang tua, sebagian lagi pada konteks adanya pandemi Covid-19. Penelitian pertama memperlihatkan betapa berubahnya keadaan pada guru ketika pandemi Covid-19 melanda. Penelitian kedua, ketiga, dan keempat memperlihatkan komunikasi antara orang tua dan anak dipengaruhi nilai-nilai yang dianut orang tua dan dapat mempengaruhi akhlak seorang anak dan prestasi anak. Adapun irisannya dengan penelian ini adalah sama-sama membahas komunikasi keluarga, khususnya orang tua dan anak. Adapun penelitian ini bertujuan untuk menjelaskan keintiman komunikasi keluarga yang dibangun pada masa social and physical distancing akibat pandemi Covid-19.

\section{METODOLOGI}

Penelitian ini menggunakan metode kualitatif dengan jenis penelitian studi kasus. Peneliti akan melakukan eksplorasi secara mendalam terhadap hasil wawancara terhadap para orang tua, baik ibu ataupun ayah, yang memiliki anak dan harus sekolah di rumah karena adanya pandemi Covid-19. Wawancara dilakukan secara langsung dengan narasumber. Alasan pemilihan metode ini dikarenakan masalah perlu dikaji secara mendetail dengan menggunakan berbagai prosedur pengumpulan data dan masalah yang dikaji pun sedang berkembang. Oleh karena itu, studi kasus paling tepat digunakan dalam penelitian kualitatif ini. Secara umum pengertian studi kasus adalah penelitian yang menempatkan sesuatu atau objek yang diteliti sebagai sebuah kasus (Sloane-Seale, 2009).

Untuk mendapatkan hasil yang lebih komprehensif dan akurat, maka penelitian ini menggunakan teknik pengumpulan data melalui triangulasi, yakni dilakukan dengan tiga cara. Pertama, observasi partisipatif yang pasif. Metode observasi ini digunakan untuk mendapatkan data-data yang berkaitan dengan kondisi fisik dan nonfisik para orang tua yang memiliki anak usia sekolah PAUD pada masa social distancing dan physical distancing akibat Pandemi Covid-19. Dalam keadaan social dan physical distancing ini, observasi dilakukan dengan cara penelaahan melalui video-video yang dibagikan di media sosial masing-masing. Subyek yang diobservasi dalam penelitian ini adalah keintiman komunikasi keluarga pada masa social dan physical distancing akibat pandemi Covid-19.

Kedua, Teknik pengumpulan data yang dilakukan adalah wawancara. Wawancara dilakukan via media Whatsapp dan Line dengan fitur video call. Wawancara yang dilakukan dalam penelitian ini adalah wawancara semi terstruktur, yakni peneliti membuat butir-butir pertanyaan tertulis Ada enam informan yang diwawancarai, yaitu tiga orang suami 
sekaligus ayah yang berprofesi sebagai pengajar di perguruan tinggi dan satu lagi pengusaha. Tiga informan lainnya adalah dua ibu bekerja yang berasal dari perkotaan dan kabupaten (pedesaan) dan satu lagi ibu yang tidak bekerja dan tinggal di perkotaan.

Ketiga, teknik pengumpulan data yang dilakukan adalah dokumentasi. Dokumentasi adalah metode pencarian data-data dengan cara mencari data mengenai hal-hal yang berupa catatan, buku, surat kabar, transkrip, dokumen, majalah yang berkaitan imbauan tinggal di rumah saja, work from home, school from home, dan social distancing akibat adanya Pandemi Covid-19.

\section{Tabel 1 Teknik Pengumpulan Data dan Capaiannya}

\begin{tabular}{cl}
\hline $\begin{array}{c}\text { Teknik Pengumpulan } \\
\text { Data }\end{array}$ & \multicolumn{1}{c}{ Capaian } \\
\hline Observasi & $\begin{array}{l}\text { Untuk mendapatkan data-data yang berkaitan dengan kondisi fisik dan } \\
\text { nonfisik para ibu yang memiliki anak usia sekolah PAUD dan SD pada } \\
\text { masa social distancing dan physical distancing akibat Pandemi Covid-19. }\end{array}$ \\
Wawancara & $\begin{array}{l}\text { Untuk mendapatkan pandangan, wawasan, gagasan, situasi, dan kondisi } \\
\text { para ibu yang memiliki anak usia sekolah PAUD dan SD pada masa social } \\
\text { distancing dan physical distancing akibat Pandemi Covid-19. } \\
\text { Dokumentasi } \\
\text { Untuk mendapatkan data yang berkaitan dengan imbauan social } \\
\text { distancing dan physical distancing, Work from Home, dan School from Home. }\end{array}$ \\
\hline
\end{tabular}

Penelitian ini berlandaskan pada enam langkah proses penelitian:

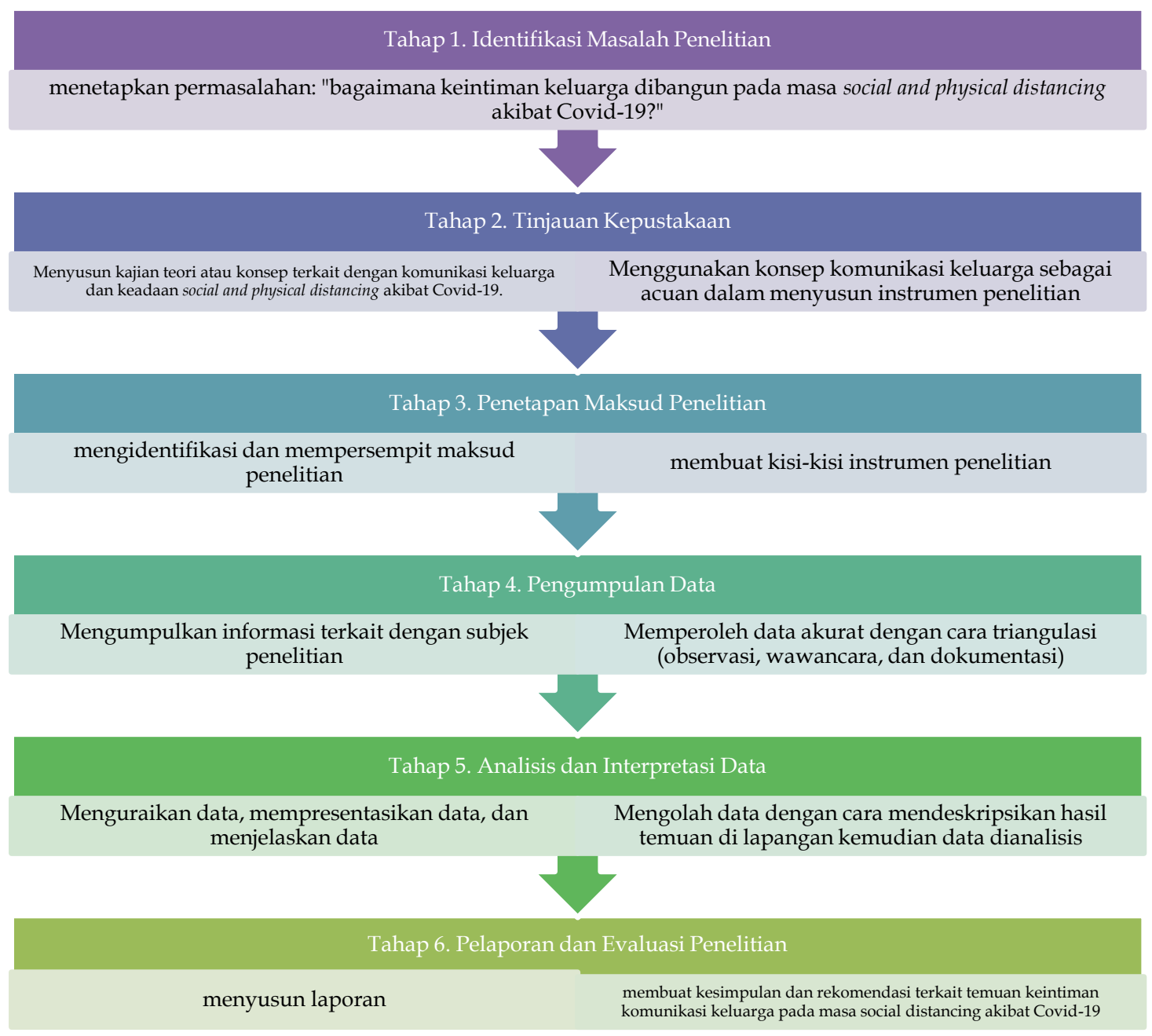

Bagan 1 Enam Tahapan Penelitian (Sloane-Seale, 2009) 


\section{HASIL DAN PEMBAHASAN}

\section{Waktu Bersama Keluarga}

Adanya kebijakan social and physical distancing yang menyebabkan kerja dan sekolah dilakukan di rumah, ada perubahan pada durasi waktu bersama keluarga, khususnya orang tua dan anak. Berikut adalah tabel yang memperlihatkan perubahan durasi waktu yang dimiliki untuk bersama anak sebelum dan sesudah penerapan social distancing.

Tabel 2 Waktu Bersama Keluarga

\begin{tabular}{|c|c|c|c|c|c|c|}
\hline Informan & 1 & 2 & 3 & 4 & 5 & 6 \\
\hline $\begin{array}{l}\text { Sebelum } \\
\text { penerapan } \\
\text { social } \\
\text { distacing }\end{array}$ & $\begin{array}{l}\text { Di rumah } \\
\text { hanya siswa } \\
\text { waktu di } \\
\text { kantor, jika } \\
\text { dihitung } 15 \\
\text { jam/minggu }\end{array}$ & 5 jam/hari & $\begin{array}{l}\text { Sisa waktu } \\
\text { di kantor } \\
\text { sepulang } \\
\text { kerja }\end{array}$ & $\begin{array}{l}7-8 \\
\mathrm{jam} / \mathrm{hari}\end{array}$ & $\begin{array}{l}2-3 \\
\mathrm{jam} / \text { hari }\end{array}$ & $\begin{array}{l}2 \text { jam/hari } \\
\text { kecuali } \\
\text { akhir pekan }\end{array}$ \\
\hline $\begin{array}{l}\text { Setelah } \\
\text { penerapan } \\
\text { social } \\
\text { distancing }\end{array}$ & $\begin{array}{l}24 \text { jam atau } \\
\text { sepanjang } \\
\text { hari }\end{array}$ & $12 \mathrm{jam} /$ hari & $\begin{array}{l}\text { Sepanjang } \\
\text { hari }\end{array}$ & 15 jam/hari & $\begin{array}{l}\text { Sepanjang } \\
\text { hari }\end{array}$ & $\begin{array}{l}2 \mathrm{jam} / \text { hari } \\
\text { kecuali } \\
\text { akhir pekan }\end{array}$ \\
\hline
\end{tabular}

Jawaban informan 1 sampai informan 5 memperlihatkan adanya perubahan durasi waktu yang dimiliki bersama keluarga sebelum dan sesudah masa social distancing akibat pandemic Covid-19. Kelima informan itu menjawab bahwa waktu dengan anggota keluarga sebelum terjadi pandemi dan muncul imbauan social distancing hanya dapat diperoleh di sela-sela pekerjaan saja, pada masa social and physical distancing justru waktu dengan keluarga semakin bertambah kuantitasnya. Di masa sebelum social and physical distancing, semua informan mengakui hanya memiliki waktu bersama keluarga dari sisa waktu kesibukan lainnya. Terutama bagi informan yang memiliki jabatan di tempat bekerjanya, waktu untuk keluarga dapat diperoleh ketika sudah pulang kerja.

Informan 1, 3, 4, dan 5 yang seorang dosen mengakui bahwa waktu dengan anak adalah sisa waktu di kantor. Apalagi keduanya memiliki jabatan struktural di kampus tempat mereka bekerja. Akan tetapi, setelah ditetapkanya kebijakan social and physical distancing, waktu untuk anak dan umumnya waktu untuk keluarga menjadi bertambah, bahkan hampir sepanjang hari.

Informan 2 yang seorang pengusaha pun mengakui sangat sulit mencuri waktu untuk keluarga dari waktu berbisnis. Padahal, notabene pekerjaan informan diatur sendiri karena mengatur usaha sendiri. Setelah penerapan social and physical distancing, waktu bersama anak-anak dapat bertambah sampai 12 jam per hari. Tidak bisa sampai 24 jam atau seharian penuh karena usaha yang dimiliki tetap harus dikontrol, apalagi pada masa sulit akibat pandemi Covid-19. Hal itu membutuhkan fokus. Tidak bisa sambil bermain dengan anak, mengontrol toko juga dilakukan.

Informan 6 tidak merasakan sama sekali karena waktu bersama keluarga tetap tidak ada perubahan, baik sebelum atau sesudah masa social distancing. Dengan profesi ibu rumah tangga, tidak menjadikan informan 6 memiliki waktu yang leluasa untuk anak-anak. Meski sepanjang waktu, secara formal ada di rumah, tetapi anggota keluarga memiliki kesibukan masing-masing. Informan 6 mengakui bahwa waktu yang bisa digunakan bersama keluarga hanya dua jam per hari. Hal tersebut terjadi karena informan 6 disibukkan dengan kerja domestik yang sering dibebankan kepada istri. 


\section{Aktivitas Bersama Anggota Keluarga}

Tabel 3. Aktivitas Bersama Anggota Keluarga

\begin{tabular}{|c|c|c|c|c|c|c|}
\hline Informan & 1 & 2 & 3 & 4 & 5 & 6 \\
\hline $\begin{array}{l}\text { Aktivitas } \\
\text { sebelum } \\
\text { penerapan } \\
\text { social } \\
\text { distacing }\end{array}$ & $\begin{array}{l}\text { Menonton } \\
\text { teve, } \\
\text { shalat } \\
\text { berjamaah } \\
\text { dan } \\
\text { mengaji, } \\
\text { jalan-jalan } \\
\text { dan } \\
\text { nonton } \\
\text { saat akhir } \\
\text { pekan, } \\
\text { dan } \\
\text { makan } \\
\text { bersama }\end{array}$ & $\begin{array}{l}\text { Kegiatan } \\
\text { yang } \\
\text { dilakukan } \\
\text { sesekali, } \\
\text { seperti } \\
\text { pengajian } \\
\text { umum, } \\
\text { belanja } \\
\text { buku di } \\
\text { akhir } \\
\text { pekan, } \\
\text { dan jalan- } \\
\text { jalan ke } \\
\text { pasar }\end{array}$ & $\begin{array}{l}\text { Bermain } \\
\text { dengan anak } \\
\text { dan } \\
\text { mengobrol } \\
\text { dengan istri }\end{array}$ & $\begin{array}{l}\text { Nonton } \\
\text { teve, } \\
\text { ngobrol, } \\
\text { makan, } \\
\text { shalat } \\
\text { berjamaah, } \\
\text { dan } \\
\text { mengerjakan } \\
\text { tugas } \\
\text { sekolah }\end{array}$ & $\begin{array}{l}\text { Shalat } \\
\text { berjamaah, } \\
\text { belajar di } \\
\text { waktu } \\
\text { malam, dan } \\
\text { belanja }\end{array}$ & $\begin{array}{l}\text { Makan } \\
\text { bersama, } \\
\text { jalan-jalan di } \\
\text { akhir pekan }\end{array}$ \\
\hline $\begin{array}{l}\text { Aktivitas } \\
\text { setelah } \\
\text { penerapan } \\
\text { social } \\
\text { distancing }\end{array}$ & $\begin{array}{l}\text { Tidak } \\
\text { banyak } \\
\text { berubah } \\
\text { hanya } \\
\text { ditambah } \\
\text { menemani } \\
\text { belajar } \\
\text { untuk } \\
\text { SFH dan } \\
\text { berjemur } \\
\text { bersama } \\
\text { di pagi } \\
\text { hari }\end{array}$ & $\begin{array}{l}\text { Shalat } \\
\text { berjamaah, } \\
\text { mengaji } \\
\text { bersama, } \\
\text { olah raga } \\
\text { bersama, } \\
\text { berjemur, } \\
\text { bercocok } \\
\text { tanam, } \\
\text { main } \\
\text { tebak- } \\
\text { tebakan, } \\
\text { dan masak } \\
\text { bersama }\end{array}$ & $\begin{array}{l}\text { Sama saja, } \\
\text { hanya } \\
\text { ditambah } \\
\text { mendampingi } \\
\text { belajar }\end{array}$ & $\begin{array}{l}\text { Sama saja. } \\
\text { Nonton } \\
\text { teve, } \\
\text { ngobrol, } \\
\text { makan, } \\
\text { shalat } \\
\text { berjamaah, } \\
\text { dan } \\
\text { mengerjakan } \\
\text { tugas } \\
\text { sekolah }\end{array}$ & $\begin{array}{l}\text { Bersih-bersih } \\
\text { rumah } \\
\text { bersama, } \\
\text { shalat } \\
\text { berjamaah, } \\
\text { makan } \\
\text { bersama, } \\
\text { bermain } \\
\text { bersama, dan } \\
\text { mendampingi } \\
\text { belajar. }\end{array}$ & $\begin{array}{l}\text { Tidak ada } \\
\text { perubahan, } \\
\text { ditambah } \\
\text { mendampingi } \\
\text { belajar dan } \\
\text { nonton dvd } \\
\text { bersama }\end{array}$ \\
\hline
\end{tabular}

Berdasarkan informasi dari keenam informan, sebelum ada imbauan karantina diri pun, mereka terbiasa melakukan aktivitas bersama anak meski dengan waktu yang sangat terbatas. Aktivitas yang dilakukan antara lain, shalat berjamaah, nonton $\mathrm{tv}$, dan belajar bersama dengan anak. Selain itu, aktivitas yang bukan aktivitas rutin tapi dilakukan secara sengaja demi menjaga kualitas interaksi, seperti datang ke pengajian umum bersama, beli buku, dan jalan-jalan.

Walaupun keenam informan mengakui terbiasa melakukan aktivitas bersama anak, tetapi informan 1, 3, 4, dan 6 menjawab tidak ada perubahan aktivitas dari masa sebelum social and physical distancing diberlakukan. Semua aktivitas sebelum social and physical distancing dilakukan juga ketika kebijakan social and physical distancing telah diberlakukan. Akan tetapi, hal yang membedakan adalah keleluasaan waktu untuk melakukan aktivitas tersebut.

Berdasarkan data tersebut, setelah adanya imbauan, aktivitas tidak dapat dikatakan bertambah secara signifikan. Namun, memang ada perubahan, terutama mengenai pendampingan belajar anak yang masa Pandemi ini dialihkan ke rumah. Pendidikan anak yang biasanya dititipkan orang tua ke sekolah, kini harus dipegang oleh orang tua. Semua informan menjawab hal baru yang dirasakan pada masa social and physical distancing ini adalah mendampingi anak belajar jarak jauh dengan gurunya di rumah menjadi tantangan sendiri. 
DOI: 10.31004/obsesi.v5i1.577

\section{Quality Time Keluarga}

Keintiman antaranggota keluarga dapat dilihat dari salah satu indikatornya, yaitu kedekatan. Kualitas waktu bersama anggota keluarga memang memerlukan durasi yang tidak sedikit. Durasi waktu mau tidak mau sangat mempengaruhi kedekatan dan keterbukaan diri antaranggota keluarga.

Namun, jika waktu yang dimiliki memang tidak banyak, bukan berarti tidak dapat membangun kualitas waktu yang baik dan ideal dengan anggota keluarga. Informan pertama mengakui kualitas waktu itu adalah waktu yang dijalani dan dihabiskan secara intens dengan anggota keluarga sehingga dapat merekatkan hubungan satu sama lain. Kualitas waktu itu terbangun dengan komunikasi di antara keluarga, sifatnya sangat dialogis.

Tabel 4. Quality Time bersama Keluarga

\begin{tabular}{|c|c|c|c|c|c|c|}
\hline Informan & 1 & 2 & 3 & 4 & 5 & 6 \\
\hline $\begin{array}{l}\text { Quality } \\
\text { Time } \\
\text { sebelum } \\
\text { penerapan } \\
\text { social } \\
\text { distacing }\end{array}$ & $\begin{array}{l}\text { Jalan-jalan, } \\
\text { makan di } \\
\text { luar, dan ke } \\
\text { bioskop } \\
\text { setiap akhir } \\
\text { pekan }\end{array}$ & $\begin{array}{l}\text { Prinsipnya } \\
\text { saat itu } \\
\text { saeutik tapi } \\
\text { patri } \\
\text { (sedikit } \\
\text { tapi lekat) }\end{array}$ & $\begin{array}{l}\text { Membuat } \\
\text { kegiatan } \\
\text { khusus } \\
\text { dengan } \\
\text { anak, } \\
\text { seperti } \\
\text { membuat } \\
\text { perapian } \\
\text { di } \\
\text { belakang } \\
\text { rumah }\end{array}$ & $\begin{array}{l}\text { Menghabiskan } \\
\text { waktu } \\
\text { bersama } \\
\text { untuk hal } \\
\text { bermanfaat }\end{array}$ & $\begin{array}{l}\text { Kegiatan } \\
\text { yang } \\
\text { dilakukan } \\
\text { bersama } \\
\text { untuk } \\
\text { mempererat } \\
\text { cinta kasih }\end{array}$ & $\begin{array}{l}\text { Melakukan } \\
\text { kegiatan } \\
\text { bersama, } \\
\text { ngobrol, dan } \\
\text { mengerjakan } \\
\text { hobi } \\
\text { bersama di } \\
\text { akhir pekan }\end{array}$ \\
\hline $\begin{array}{l}\text { Quality } \\
\text { Time } \\
\text { setelah } \\
\text { penerapan } \\
\text { social } \\
\text { distancing }\end{array}$ & $\begin{array}{l}\text { Segala hal } \\
\text { dilakukan di } \\
\text { rumah, } \\
\text { mulai dari } \\
\text { berjemur, } \\
\text { nonton film } \\
\text { bersama } \\
\text { tidak di } \\
\text { bioskop, } \\
\text { makan } \\
\text { bersama di } \\
\text { rumah, } \\
\text { belajar lebih } \\
\text { intens, dan } \\
\text { usai salat } \\
\text { menyelipkan } \\
\text { cerita-cerita } \\
\text { sejarah, } \\
\text { pengelaman } \\
\text { hidup. }\end{array}$ & $\begin{array}{l}\text { Kualitas } \\
\text { waktu jadi } \\
\text { lebih terasa } \\
\text { dan jadi } \\
\text { lebih baik }\end{array}$ & $\begin{array}{l}\text { Kegiatan } \\
\text { khusus } \\
\text { tetap ada } \\
\text { bahkan } \\
\text { kualitas } \\
\text { waktu } \\
\text { lebih baik } \\
\text { karena } \\
\text { durasi } \\
\text { yang lebih } \\
\text { lama }\end{array}$ & $\begin{array}{l}\text { Sama saja } \\
\text { pada } \\
\text { prinsipnya itu, } \\
\text { tetapi lebih } \\
\text { intens karena } \\
\text { waktu yang } \\
\text { dimiliki lebih } \\
\text { banyak. }\end{array}$ & $\begin{array}{l}\text { Lebih } \\
\text { banyak hal } \\
\text { yang bisa } \\
\text { dilakukan } \\
\text { bersama } \\
\text { karena } \\
\text { waktu yang } \\
\text { lebih } \\
\text { leluasa } \\
\text { sehingga } \\
\text { interaksi } \\
\text { pun intens }\end{array}$ & $\begin{array}{l}\text { Sama saja. } \\
\text { Akhir pekan } \\
\text { adalah } \\
\text { waktu yang } \\
\text { paling } \\
\text { leluasa } \\
\text { untuk } \\
\text { beraktivitas } \\
\text { bersama }\end{array}$ \\
\hline
\end{tabular}

Berdasarkan penjelasan informan 1, kualitas waktu yang baik bersama keluarga tidak sekadar bicara durasi, melainkan intensitas dan dialogis. Tidak akan tercipta kualitas waktu yang baik meski ada di tempat yang sama seharian, jika tidak ada dialog antaranggota keluarga di dalamnya. Informan 1 mengatakan bahwa akan tetap memelihara ritme yang terbentuk akibat social distancing ini. Ia akan mempertahankan kualitas waktu yang telah terbangun dan aktivitas positif yang dilakukan ketika imbauan social distancing ini telah berakhir. 
Senada dengan informan 2, 3, 4, dan 5, kualitas waktu itu tidak selalu bicara lamanya durasi, tetapi bagaimana mengoptimalkan setiap waktu dan diisi dengan hal-hal yang menyenangkan dan bermanfaat untuk semua anggota keluarga. Terlebih lagi, apabila kegiatan itu dapat juga mempererat tali kasih di antara anggota keluarga. Namun, tidak dapat dipungkiri, durasi waktu yang cukup banyak untuk di rumah membuat aktivitas bersama anak dapat lebih banyak dilakukan. Informan 2, 3, 4, dan 5 pun menyatakan akan tetap mempertahankan aktivitas yang sudah terbiasa sekarang. Aktivitas yang dilakukan bersama anggota keluarga lainnya saat masa karantina diri ini bukan sekadar formalitas karena seluruh anggota keluarga benar-benar hadir secara fisik dan batin.

Adapun informan 6 sama tidak merasakan perubahan, yaitu hanya pada waktu akhir pekanlah kualitas waktu bersama anak dapat dirasakan karena pada akhir pekan pekerjaan domestik bisa dibagi bersama suami. Jadi, baik sebelum social and physical distancing atau sesudah social and physical distancing, untuk informan 6 yang sehari-hari berperan sebagai ibu rumah tangga tidak ada perubahan.

\section{Pembahasan \\ Keintiman Keluarga Selama Social Distancing}

Keintiman berkaitan erat dengan kestabilan. Dalam hal ini, ada banyak hal yang dapat dikaitkan dengan kestabilan. Salah satunya adalah kestabilan waktu bersama seluruh anggota keluarga, khususnya orang tua dan anak. Keintiman dapat mempengaruhi kepada proses informasi, menjalankan peran masing-masing, mengembangkan tujuan dan target, mendefinisikan diri sendiri dengan kokoh, dan mengonstruksi pesan (Trenholm, Sarah \& Jensen, 2004). Kebersamaan yang intens akan mempererat ikatan, terutama ketika masalah muncul di dalam keluarga (Triwardhani \& Chaerowati, 2019). Dengan keintiman waktu yang diperoleh dari masa social and physical distancing ini, tiap anggota keluarga seharusnya dapat lebih maksimal dalam menjalankan peran masing-masing di keluarga dan membangun jembatan pemahaman yang akan mempererat hubungan antaranggota keluarga.

Hal yang terjadi kepada informan 6 menarik untuk diamati lebih jauh. Sejatinya, ketika kelima informan lain yang pada akhirnya memiliki durasi lama bersama keluarga dibanding hari biasa, justru informan keenam yang sehari-hari ada di rumah tidak mengalami perubahan keadaan. Adanya anggota keluarga di rumah sepanjang hari, tidak serta merta membuatnya dapat menghabiskan waktu bersama.

Dari hal yang dialami informan 6, kestabilan dalam konteks keintiman antaranggota keluarga, tidak hanya dapat dilihat dari durasi atau lamanya. Akan tetapi, pemahaman pada porsi dan peran masing-masing itu diperlukan untuk menjaga kestabilan yang melekatkan keintiman. Salah satu karakteristik dari keluarga adalah adanya recognition of responsibilities atau mengenal dan memahami tanggung jawab masing-masing (DeVito, 2008). Setiap anggota keluarga memiliki tanggung jawab dan peran masing-masing. Tidak hanya bicara tanggung jawab finansial yang biasanya melekat pada kepala keluarga saja, tetapi juga tanggung jawab emosional.

Kejadian yang dialami informan 6 menunjukkan walaupun ada anggota keluarga sepanjang hari, dia tetap hanya bisa menghabiskan waktu bersama kurang lebih dua jam saja karena disibukkan dengan pekerjaan domestik. Dalam hal ini, suami, meski bekerja di rumah karena ada imbauan karantina diri, tetap memposisikan diri sebagai penanggung jawab finansial saja. Suami tidak merasa perlu untuk mengubah ritme sehari-hari walaupun sekarang bekerja di rumah dan seharian ada di rumah.

Waktu yang tersita dengan pekerjaan domestik membuat informan ini kehilangan keintiman dengan anggota keluarga. Salah satu indikator dari keintiman adalah kemampuan memahami peran dalam suatu tempat dan kondisi. Kemampuan itu disebut sebagai role competence, yaitu kemampuan untuk beradaptasi terhadap peran diri sendiri dan orang lain (Trenholm, Sarah \& Jensen, 2004). 
Ketidakluwesan suami memainkan perannya baik sebelum masa social and physical distancing dan sesudah social and physical distancing menunjukkan ada keintiman yang tidak terbangun. Ketidakpahaman pada porsi, peran, dan kebutuhan anggota keluarga ini jugalah yang menyebabkan kestabilan durasi waktu bersama keluarga tidak maksimal.

Hal ini pun sangat dipengaruhi oleh tipe pola komunikasi keluarga masing-masing. Ada empat pola komunikasi keluarga yang umum pada keluarga inti, yaitu sebagai berikut.

a. Pola Komunikasi Persamaan (Equality Pattern)

Tiap individu berbagi hak yang sama dalam kesempatan berkomunikasi. Peran tiap orang dijalankan secara merata. Komunikasi berjalan dengan jujur, terbuka, langsung, dan bebas dari pembagian kekuasaan. Semua orang memiliki hak yang sama dalam proses pengambilan keputusan. Keluarga mendapatkan kepuasan tertinggi bila ada kesetaraan.

b. Pola Komunikasi Seimbang Terpisah (Balance Split Pattern)

Kesetaraan hubungan tetap terjaga, namun dalam pola ini tiap orang memiliki daerah kekuasaan yang berbeda dari yang lainnya. Tiap orang dilihat sebagai ahli dalam bidang yang berbeda. Sebagai contoh, dalam keluarga normal/tradisional, suami dipercaya dalam urusan bisnis atau politik. Istri dipercaya untuk urusan perawatan anak dan memasak. Namun pembagian peran berdasarkan jenis kelamin ini masih bersifat fleksibel. Konflik yang terjadi dalam keluarga tidak dipandang sebagai ancaman karena tiap individu memiliki area masing-masing dan keahlian sendiri.

c. Pola Komunikasi Tak Seimbang Terpisah (Unbalanced Split Pattern)

Satu orang mendominasi, satu orang dianggap sebagai ahli lebih dari yang lainnya. Satu orang inilah yang memegang kontrol, seseorang ini biasanya memiliki kecerdasan intelektual lebih tinggi, lebih bijaksana, atau berpenghasilan lebih tinggi. Anggota keluarga yang lain berkompensasi dengan cara tunduk pada seseorang 6 tersebut, membiarkan orang yang mendominasi itu untuk memenangkan argumen dan pengambilan keputusan sendiri.

d. Pola Komunikasi Monopoli (Monopoly Pattern)

Satu orang dipandang sebagai pemegang kekuasaan. Satu orang ini lebih bersifat memberi perintah dari pada berkomunikasi. la memiliki hak penuh untuk mengambil keputusan sehingga jarang atau tidak pernah bertanya atau meminta pendapat dari orang lain. Pemegang kuasa memerintahkan kepada yang lain apa yang boleh dan tidak boleh dilakukan. Maka anggota keluarga yang lainnya meminta izin, meminta pendapat, dan membuat keputusan berdasarkan keputusan dari orang tersebut (De Vito, 2013).

Peran masing-masing yang dijalankan menunjang komunikasi keluarga yang efektif, termasuk komunikasi antara orang tua dan anak. Pada masa social and physical distancing sekarang ini, dalam menjalankan peran orang tua ada tambahan, yaitu menemani, mendampingi, dan membimbing anak belajar selama masa SFH (School from Home) atau PJJ (Pembelajaran Jarak Jauh). Ini dikatakan sebuah aktivitas baru oleh seluruh informan karena selama ini, orang tua memberikan peran itu kepada guru di sekolah.

Pendidikan memang sudah selayaknya keluarga tidak lepas tangan. Ki Hajar Dewantara memiliki konsep "Tri Sentra Pendidikan", yaitu sentra keluarga, sentra perguruan, dan sentra masyarakat. Dalam konteks sentra keluarga, pendidikan keluarga telah melahirkan konsep "among", di mana konsep among ini menuntut para orang tua untuk bersikap, yaitu (a) ing ngarso sun tolodo, (b) ing madya mangun kasra, (c) tut wuri handayani. Dalam konteks sentra keluarga, Ki Hajar Dewantara sangat peduli dalam memperhatikan, bahkan meminta para orang tua untuk mendidik anak-anak sejak usia dini (alam keluarga). Alam keluarga itu adalah suatu tempat yang sebaik-baiknya untuk melakukan pendidikan kesusilaan dan kesosialan sehingga boleh dikatakan bahwa keluarga itu tempat pendidikan yang lebih sempurna sifat dan wujudnya daripada tempat-tempat lainnya untuk melangsungkan pendidikan ke arah kecerdasan budi pekerti (pembentukan watak individual) dan sebagai persediaan hidup kemasyarakatan (Jailani, 2014). 
Jailani (2014) dalam penelitian yang berjudul "Teori Pendidikan Keluarga dan Tanggung Jawab Orang Tua dalam Pendidikan Anak Usia Dini" menyimpulkan bahwa orang tua (ayah-ibu) memiliki tanggung jawab yang besar dalam mendidik anak-anak dalam keluarga. Fungsi-fungsi dan peran orang tua tidak hanya sekadar memenuhi kebutuhan fisik anak berupa kebutuhan makan dan minum, pakaian, tempat tinggal tapi juga tanggung jawab orang tua jauh lebih penting dari itu adalah berupa perhatian, bimbingan, arahan, motivasi, dan pendidikan, serta menanamkan nilai-nilai bagi masa depannya.

Setelah ada imbauan belajar di rumah, orang tua kembali memerankan fungsi sentra keluarga sebagai sentra awal pendidikan. Kelima informan mengakui tidak merasa kesulitan mendampingi anak dalam program belajar di rumah karena memang sudah terbiasa sebelum ada imbauan karantina diri ini. Akan tetapi informan 6 sempat mengalami kendala terutama dalam mengendalikan mood atau suasana hati anak untuk belajar. Karantina diri karena kebijakan social distancing telah menciptakan suasana ketidakpastian bagi sebagian orang tua yang dapat meningkatkan stres atau khawatir berlebih (Yarımkaya \& Esentürk, 2020).

Tantangan hadir di sini, orang tua dituntut untuk kreatif dan cerdas membangun suasana belajar di rumah sehingga anak dapat fokus, konsentrasi, dan termotivasi belajar sebagaimana di sekolah. Ada beberapa kegiatan bimbingan orang tua dalam belajar, di antaranya (a) menyediakan fasilitas belajar; (b) memberikan motivasi atau mengawasi kegiatan belajar anak di rumah; (c) mengawasi penggunaan waktu belajar anak di rumah; (d) mengenal kesulitan-kesulitan anak dalam belajar; (e) menolong anak mengatasi kesulitannya dalam belajar (Qomaruddin, 2018).

Dengan adanya imbauan social distancing ini, orang tua dapat menjadi teman belajar sekaligus guru yang benar-benar memahami anak. Orang tua juga pada akhirnya akan mengetahui letak kesulitan atau kelebihan yang dimiliki anak secara akademis. Orang tua pun akan lebih empati pada peran dan fungsi guru di sekolah. Orang tua pun dituntut menguasai teknologi dan digital pada masa social distancing karena PJJ (pembelajaran jarak jauh) hampir semuanya menggunakan teknologi. Digital teknologi hampir menjadi bagian dari aspek hidup sehari-hari, salah satunya internet (Seifert, 2020). Orang tua tidak cukup menyediakan fasilitas, tetapi pada masa social and physical distancing, orang tua harus menguasai.

Saat masa social and physical distancing ini, orang tua pun dituntut kreatif agar anak tidak bosan berada di rumah. Aktivitas membaca, bernyanyi, dan bermain menjadi hal yang sering dipilih informan untuk menemani putra atau putri mereka yang masih tergolong anak usia dini. Aktivitas membaca yang dilakukan salah satunya adalah membacakan cerita atau membuat cerita dari gambar. Aktivitas membaca yang menyenangkan akan membuat anak menikmati kegiatan tersebut (Permatasari, Inten, Mulyani, \& Rahminawati, 2019). Informan mengakui, masa social and physical distancing ini mereka harus aktif memilah buku atau menggilir buku yang dibaca agar anak tidak bosan. Jika anak sudah bosan dengan buku yang dimiliki, salah satu informan sering mencetak gambar dari internet lalu bersama anak membuat cerita sendiri.

Untuk aktivitas bermain ada beragam permainan yang dilakukan. Mulai dari permainan balok, permainan kartu, dan bermain peran. Dengan bermain peran, anak dapat menyampaikan apa yang dipikirkan, dirasakan, serta imajinasinya yang unik (Inten, 2017). Salah satu informan yang merupakan seorang ibu yang biasa bekerja sebagai pengajar sering melakukan aktivitas bermain peran dengan anaknya untuk mengisi masa karantina diri saat social and physical distancing. Bermain peran yang dilakukannya dengan anak di antaranya adalah ibu jadi dokter anak jadi pasien. Dalam permainan bermain peran itu, ibu bisa memberikan pesan-pesan tentang Covid-19 sambil bermain.

Bernyanyi bersama pun menjadi alternatif para orang tua yang menjadi informan di penelitian ini bersama anak-anaknya. Bernyanyi adalah salah satu alternatif cara belajar yang dapat digunakan. Ada banyak manfaat bernyanyi, yaitu meningkatkan kemampuan 
wicara anak, mengenalkan aneka kata, dan menambahkan wawasan mengenai konsep sesuatu tanpa anak merasa tertekan seperti belajar (Inten, Permatasari, Mulyani, Komunikasi, \& Bandung, 2016). Bagi anak, belajar akan mencapai maksimal ketika sedang berada pada playful mind atau ketika merasa gembira (Triwardhani, 2006).

Pada masa social and physical distancing seperti sekarang ini, komunikasi keluarga yang tepat adalah yang berorientasi kepada dialog atau disebut conversation orientation (DeVito, 2008). Keluarga dengan tipe ini sangat membebaskan anggota keluarga mengungkapkan apa yang dirasakan dan dipikirkan secara verbal. Tipikal keluarga yang conversation orientation ini sangat menghargai opini anggota keluarga dan biasanya juga tinggi tingkat konformitasnya. Kesepakatan seluruh anggota keluarga sangat dijunjung tinggi. Orang tua juga memiliki banyak kesempatan untuk mendengarkan anak, yaitu dengan memahami, menanggapi, dan menanyakan perasaan atau opini dari anak (Ratnasari, 2007).

Dengan adanya imbauan social and physical distancing yang menyebabkan bekerja dan belajar di rumah, tipe keluarga seperti ini tentu sangat siap dengan keadaan yang berubah dari hari-hari biasanya. Terutama persoalan mengenai menemani anak PJJ (Pembelajaran Jarak Jauh) dengan guru di sekolah atau ketika harus menjadi pengganti guru di rumah. Karena keterbukaan yang telah dibiasakan dengan mengungkapkan apa yang dipikirkan dan dirasakan secara bebas, akan memudahkan ibu atau ayah menemani anaknya belajar di rumah.

Berbicara kualitas waktu antara sebelum dan sesudah imbauan karantina diri, informan 1 sampai informan 5 pada umumnya sepakat bahwa setelah imbauan leluasa untuk membangun kualitas waktu yang baik dengan anggota keluarga. Interval waktu dalam interaksi sedikit banyak mempengaruhi keintiman (Sumitra, 2015). Walaupun sebelum imbauan, komunikasi dengan antaranggota keluarga sudah terbangun, tetapi setelah adanya imbauan waktu yang dimiliki lebih banyak dan lebih leluasa membangun quality time bersama.

Setiap orang tentu punya versi quality time masing-masing. Ada yang bicara bukan masalah durasi, tetapi kelekatan yang dibangun. Ada juga yang berpendapat durasi sangat menentukan kualitas waktu antara orang tua dan anak. Adanya kebijakan social and physical distancing akibat pandemi Covid-19, membawa ritme baru dalam interaksi antara orang tua dan anak. Aktivitas dan ritme yang selama masa social and physical distancing dilakukan bersama akan terbiasa dilakukan pada masa selanjutnya. Orang tua dan anak akan terbiasa melakukan segala hal bersama, mulai dari belajar, berjemur di pagi hari, dan bermain bersama. Jika biasanya sebelum masa social and physical distancing membuat quality time di luar rumah dengan nonton di bioskop atau jajan di luar, setelah social and physical distancing membentuk ikatan erat antara orang tua dan anak semuanya terpusat di rumah. Dengan ritme baru ini, aktivitas bersama bukan sekadar formalitas, tetapi seluruh anggota keluarga betul-betul hadir secara fisik dan batin.

\section{SIMPULAN}

Adanya kebijakan social distancing dan physical distancing ini menjadikan rumah sebagai pusat aktivitas. Dari hasil penelitian diperlihatkan bahwa memang perlu ada satu moment seperti sekarang ketika setiap anggota keluarga memiliki banyak waktu di rumah sehingga rumah tidak sekadar tempat singgah. Orang tua beraktivitas bersama dengan anak, mulai dari berjemur bersama, beribadah bersama, bermain bersama, sampai mendampingi anak belajar yang biasanya diserahkan pada guru di sekolah. Kemampuan memahami peran masing-masing antaranggota keluarga adalah hal yang penting juga dalam beraktivitas bersama selama masa social distancing dan physical distancing karena qualiy time itu bukan bicara kuantitas, tetapi kualitas dari kebersamaan juga. Selain itu, kemampuan menyampaikan dan memahami pesan ketika orang tua berkomunikasi pada anak pada masa social distancing dan physical distancing dapat membangun keintiman komunikasi keluarga. 


\section{UCAPAN TERIMA KASIH}

Peneliti mengucapkan terima kasih kepada para informan yang telah berkenan berbagi informasi mengenai aktivitas bersama keluarga pada masa masa social distancing dan physical distancing. Peneliti juga mengucapkan terima kasih kepada Dewan Redaksi Jurnal Obsesi yang telah memberi kesempatan kepada peneliti untuk berbagi ilmu sehingga bisa memberi kontribusi untuk perkembangan ilmu pengetahuan.

\section{DAFTAR PUSTAKA}

Baloran, E. T. (2020). Knowledge, Attitudes, Anxiety, and Coping Strategies of Students during COVID-19 Pandemic. Journal of Loss and Trauma, 0(0), 1-8. https:/ / doi.org/10.1080/15325024.2020.1769300

BBC Indonesia. (2020). Virus corona: Jokowi umumkan langkah pengendalian Covid-19, tapi tanpa "komando nasional" - BBC News Indonesia. BBC News, 1-9. Retrieved from https://www.bbc.com/indonesia/indonesia-51897307

CNN Indonesia. (2020). Cegah Penyebaran Corona, Jabar Liburkan Sekolah Dua Pekan. Retrieved from https://www.cnnindonesia.com

De Vito, J. (2013). The Interpersonal Communication Book 4th edition. USA: Pearson.

DeVito, J. a. (2008). The Interpersonal Communication Book. PsycCRITIQUES, 32, 2009. https:// doi.org/10.1037/026727

Inten, D. N. (2017). Pengembangan Keterampilan Berkomunikasi Anak Usia Dini Melalui Metode Bermain Peran. Mediator: Jurnal Komunikasi, 10(1), 109-120. https:// doi.org/10.29313/mediator.v10i1.2712

Inten, D. N., Permatasari, A. N., Mulyani, D., Komunikasi, F. I., \& Bandung, U. I. (2016). Literasi dini melalui teknik bernyanyi 1E3. 3(2013), 70-91.

Jailani, M. S. (2014). Teori Pendidikan Keluarga dan Tanggung Jawab Orang Tua dalam $\begin{array}{lllll}\text { Pendidikan Anak Usia Dini. Nadwa, } 245 . & \end{array}$ https:// doi.org/10.21580/nw.2014.8.2.580

John, A., Halliburton, A., \& Humphrey, J. (2013). Child-mother and child-father play interaction patterns with preschoolers. Early Child Development and Care, 183(3-4), 483-497. https:/ / doi.org/10.1080/03004430.2012.711595

Johnson, M. D. (2016). Great Myths of Intimate Relationships. In Great Myths of Intimate Relationships. https:// doi.org/10.1002/9781118817469

Kurniadi, O. (2001). Pengaruh Komunikasi Keluarga terhadap Prestasi Belajar Anak. Mediator, 2(2), 267-290. https://doi.org/https://doi.org/10.29313/mediator.v2i2.736

Masters, W. H., Johnson, V. E., dan K. R. C. (1992). Human Sexuality. New York: Harper Collins Publisher.

Muftie, Z. (2017). Pengaruh Komunikasi Orang Tua dalam Rumah Tangga terhadap Akhlak Anak Sehari-Hari. Atthulab: Islamic Religion Teaching and Learning Journal, 2(1). https:// doi.org/10.15575/ath.v2i1.2725

Nafi, M. (2020). Melawan Virus Corona dari Rumah. Katadata.Co.Id. Retrieved from https:/ / katadata.co.id/berita/2020/03/17/melawan-virus-corona-dari-rumah

Permatasari, A. N., Inten, D. ., Mulyani, D., \& Rahminawati, N. (2019). Literasi Dini. Bandung: Mediamore.

Qomaruddin, Q. (2018). Pendampingan Orangtua terhadap Pendidikan Anak. CENDEKIA : Jurnal Studi Keislaman, 3(1). https:// doi.org/10.37348/cendekia.v3i1.41

Rakhmat, J. (1999). Psikologi Komunikasi. Bandung: Simbiosa Media Rekatama.

Ratnasari, A. (2007). Komunikasi Harmonis Orang Tua dengan Anak. Mediator: Jurnal Komunikasi, 8(2), 345-352. https:// doi.org/10.29313/mediator.v8i2.1247

Sari, A. (2014). Komunikasi dan Pola Asuh Anak Balita - Remaja dalam Keluarga Betawi $\begin{array}{llll}\text { Jakarta dan } \text { Bekasi. Jurnal } & 63 .\end{array}$ https:// doi.org/10.24329/aspikom.v2i2.60 
DOI: 10.31004/obsesi.v5i1.577

Seifert, A. (2020). The Digital Exclusion of Older Adults during the COVID-19 Pandemic. Journal of Gerontological Social Work, Vol. 00, pp. 1-3. https:/ / doi.org/10.1080/01634372.2020.1764687

Sloane-Seale, A. (2009). Research Design: Qualitative, Quantitative, and Mixed Methods Approaches. Canadian Journal of University Continuing Education, 35(2). https://doi.org/10.21225/d54s3d

Su, L., Ma, X., Yu, H., Zhang, Z., Bian, P., Han, Y., ... Gai, Z. (2020). The different clinical characteristics of corona virus disease cases between children and their families in China-the character of children with COVID-19. Emerging Microbes and Infections, 9(1), 707-713. https://doi.org/10.1080/22221751.2020.1744483

Sumitra, B. (2015). Keintiman Komunikasi Interpersonal Termediasi melalui New Media. Universitas Sultan Ageng Tirtayasa.

Talidong, K. J. B., \& Toquero, C. M. D. (2020). Philippine Teachers' Practices to Deal with Anxiety amid COVID-19. Journal of Loss and Trauma, 1-7. https://doi.org/10.1080/15325024.2020.1759225

Trenholm, Sarah \& Jensen, A. (2004). Interpersonal Communication. New York: Oxford University Press.

Triwardhani, I. J. (2006). Komunikasi Persuasif pada Pendidikan Anak. Mediator: Jurnal Komunikasi, 7(1), 77-84. https:/ / doi.org/10.29313/mediator.v7i1.1220

Triwardhani, I. J., \& Chaerowati, D. L. (2019). Interpersonal communication among parents and children in fishermen village in cirebon Indonesia. Jurnal Komunikasi: Malaysian Journal of Communication, 35(2), 277-292. https://doi.org/10.17576/JKMJC-2019-350217

Yarımkaya, E., \& Esentürk, O. K. (2020). Promoting physical activity for children with autism spectrum disorders during Coronavirus outbreak: benefits, strategies, and examples. International Journal of Developmental Disabilities, 0(0), 1-6. https://doi.org/10.1080/20473869.2020.1756115 